\title{
Letters
}

\section{Secreted protein acidic and rich in cysteine (SPARC) in patients with diabetic nephropathy and tubulointerstitial injury}

\section{Dear Sir,}

Recently, tubulointerstitial injury has been recognised as a major feature of diabetic nephropathy and an important predictor of renal dysfunction [1]. Some matricellular proteins are likely to be important contributors to progressive tubulointerstitial injury. Secreted protein acidic and rich in cysteine (SPARC) has been implicated as counteradhesive, antiproliferative and antiangiogenic glycoprotein associated with accumulation of extracellular matrix (ECM) in renal diseases [2]. In experimental diabetes, a reduction in SPARC mRNA expression was found in the early phase of nephropathy [3]. Conversely, co-expression of SPARC with TGF-beta and type I collagen in the interstitium in an experimental model with associated tubulointerstitial injury has been described [4]. Therefore, SPARC can be considered as a matricellular protein that seems to function in tissue remodeling in response to renal injury. The role of SPARC in human diabetic nephropathy, however, especially in relation to tubulointerstitial lesions, has not been extensively investigated. We measured the serum concentrations of SPARC in 40 patients with Type II (non-insulin-dependent) diabetes mellitus who underwent renal biopsy (30 men and 10 women, serum creatinine concentrations 26.6 to $159.1 \mu \mathrm{mol} / \mathrm{l})$. Serum SPARC was measured using a sandwich ELISA (Takara Shuzo, Otsu, Japan) [5]. The severity of the diffuse glomerular lesions was graded as D1 (mild), D2 (moderate) or D3 (severe), as reported previously in detail [6]. The severity of the tubulointerstitial lesions was determined by a semiquantitative estimate of the space occupied by the fibrous tissue or interstitial infiltrates or both using the following criteria: T1 (damaged area $\leq 10 \%$ ); T2 (damaged area $11-30 \%$ ); and $\mathrm{T} 3$ (damaged area $\geq 31 \%$ ). Overall renal injury was categorised as type A (minor lesions; D1 and T1), type B (glomerular lesions predominant; $\geq \mathrm{D} 2$ and $\leq \mathrm{T} 2$ ), type $\mathrm{C}$ (severe glomerular lesions with widespread tubulointerstitial changes; D3 and T3), or type D (tubulointerstitial lesions

Corresponding author: , Dr M. Kanauchi, First Department of Internal Medicine, Nara Medical University, 840, Shijo-cho, Kashihara, Nara 634-0813, Japan predominant $\leq \mathrm{D} 1$ and $\geq \mathrm{T} 2$ ). Differences between the four groups were assessed by analysis of variance (ANOVA) followed by Scheffe's test for multiple comparisons. Statistical significance was set at $p<0.05$.

Serum concentrations of SPARC were significantly higher in type $\mathrm{C}$ than in type A, and were significantly higher in type $\mathrm{D}$ than in types A or B. Significantly elevated serum creatinine concentrations and significantly decreased creatinine clearance were detected in type C. Other clinical and laboratory data including age, body mass index, duration of diabetes, urinary albumin excretion, and $\mathrm{HbA}_{1 \mathrm{c}}$ were also shown (Table 1 ). Stepwise multiple regression analysis were carried out to identify variables contributing to changes in SPARC concentrations. The severity of the tubulointerstitial lesions (standard regression coefficient $\beta=0.516, p=0.0012$ ), urinary albumin excretion $(\beta=0.410, p=0.0048)$, and serum creatinine $(\beta=-0.293, p=0.0342)$ were independently associated with SPARC levels $\left(R^{2}=0.514, p<0.0001\right)$.

An experimental study demonstrated that administration of recombinant SPARC in rats with anti-Thy 1 nephritis stimulated expression of TGF-beta and type I collagen in vivo [7]. SPARC can also induce the expression of metalloproteases, indicating a potential role in the regulation of ECM turnover [8]. We found that the significantly elevated serum concentrations of SPARC were detected in diabetic patients with widespread tubulointerstitial lesions associated with and without advanced glomerular lesions. A few hypotheses have been proposed for the potential mechanisms of SPARC in the development of interstitial fibrosis. Firstly, SPARC could regulate the deposition of ECM. Secondly, SPARC could induce ECM production by stimulating TGF-beta. Thirdly, SPARC could modulate the proliferation or migration or both of interstitial fibroblasts. Thus, increased levels of SPARC could play a part in tissue remodelling in response to tubulointerstitial injury. On the other hand, SPARC is a low molecular weight protein $\left(43000 \mathrm{M}_{\mathrm{r}}\right)$ and accumulation could cause in renal failure. In this study, however, subjects with end-stage renal disease were excluded (all subjects underwent renal biopsy, if serum creatinine concentrations were less than $159.1 \mu \mathrm{mol} / \mathrm{l})$. In summary, our study provides the first documentation that SPARC is implicated in the development of tubulointerstitial lesions in human diabetic nephropathy.

Yours faithfully,

M. Kanauchi, M. Nishioka, K. Dohi 
Table 1. Clinical characteristics and serum levels of SPARC

\begin{tabular}{|c|c|c|c|c|c|c|c|c|c|c|c|}
\hline \multirow[t]{2}{*}{ Group } & \multicolumn{2}{|c|}{ Definition } & \multirow[t]{2}{*}{$n$} & \multirow{2}{*}{$\begin{array}{l}\text { Age } \\
\text { (yrs) }\end{array}$} & \multirow{2}{*}{$\begin{array}{l}\text { BMI } \\
\left(\mathrm{kg} / \mathrm{m}^{2}\right)\end{array}$} & \multirow{2}{*}{$\begin{array}{l}\text { Duration } \\
\text { of diabetes } \\
\text { (yrs) }\end{array}$} & \multirow{2}{*}{$\begin{array}{l}\text { U-Alb } \\
\text { (mg/day) }\end{array}$} & \multirow{2}{*}{$\begin{array}{l}\text { Scr } \\
(\mathrm{mg} / \mathrm{dl})\end{array}$} & \multirow{2}{*}{$\begin{array}{l}\text { Ccr } \\
(\mathrm{ml} / \mathrm{min})\end{array}$} & \multirow[t]{2}{*}{$\mathrm{HbA}_{1 \mathrm{c}}(\%)$} & \multirow{2}{*}{$\begin{array}{l}\text { SPARC } \\
(\mathrm{ng} / \mathrm{ml})\end{array}$} \\
\hline & DGS & TIL & & & & & & & & & \\
\hline A & D1 & & 19 & & & & & & & & \\
\hline B & $\geq \mathrm{D} 2$ & $\leq \mathrm{T} 2$ & 10 & & & & 529 & $0.90 \pm 0.41$ & & 1.00 & 10.7 \\
\hline $\mathrm{C}$ & D3 & T3 & 7 & $66.8 \pm 3.3^{\mathrm{d}}$ & $22.7 \pm 2.5$ & $18.0 \pm 8.2^{\mathrm{a}}$ & $2883 \pm 1111^{\mathrm{a}, \mathrm{c}, \mathrm{e}}$ & $1.14 \pm 0.20^{\mathrm{b}}$ & $42 \pm 14^{\mathrm{a}, \mathrm{d}, \mathrm{e}}$ & $8.07 \pm 3.06$ & $65.0 \pm 25.3^{\mathrm{a}}$ \\
\hline $\mathrm{D}$ & D1 & $\geq \mathrm{T} 2$ & 4 & $59.2 \pm 4.4$ & $21.7 \pm 1.5$ & $8.3 \pm 5.8$ & $20 \pm 4$ & $0.73 \pm 0.21$ & $82 \pm 10$ & $7.30 \pm 0.94$ & $60.2 \pm 10.9^{\mathrm{a}, \mathrm{d}}$ \\
\hline
\end{tabular}

Data are means \pm SD.

${ }^{\mathrm{a}} p<0.01$ vs type $\mathrm{A} ;{ }^{\mathrm{b}} p<0.05$ vs type $\mathrm{A} ;{ }^{\mathrm{c}} p<0.01$ vs type $\mathrm{B}$;

${ }^{\mathrm{d}} p<0.05$ vs type $\mathrm{B} ;{ }^{\mathrm{e}} p<0.05$ vs type $\mathrm{D}$.

\section{References}

1. Gilbert RE, Cooper ME (1999) The tubulointerstitium in progressive diabetic kidney disease. Kidney Int 56: $1627-1637$

2. Motamed K, Sage EH (1997) Regulation of vascular morphogenesis by the matricellular protein SPARC. Kidney Int 51: 1383-1387

3. Gilbert RE, McNally PG, Cox A et al. (1995) SPARC gene expression is reduced in early diabetes-related kidney growth. Kidney Int 48: 1216-1225

4. Pichler RH, Hugo C, Shankland SJ et al. (1996) SPARC is expressed in renal interstitial fibrosis and in renal vascular injury. Kidney Int 50: 1978-1989

5. Kamihagi K, Katayama M, Ouchi R, Kato I (1994) Osteonectine/SPARC regulates cellular secretion rates of fi-

BMI, body mass index; U-Alb, urinary albumin; Scr, serum creatinine; SPARC, secreted protein acidic and rich in cysteine; DGS, diabetic glomerulosclerosis; TIL, tubulointerstitial lesion

bronectin and laminin extracellular matrix proteins. Biochem Biophys Res Commun 200: 423-428

6. Iwano M, Kubo A, Nishino T et al. (1996) Quantification of glomerular TGF-beta1 mRNA in patients with diabetes mellitus. Kidney Int 49: 1120-1126

7. Bassuk JA, Pichler R, Rothmier JD, Pippen J (2000) Induction of TGF-beta1 by the matricellular protein SPARC in a rat model of glomerulonephritis. Kidney Int 57: 117-128

8. Tremble PM, Lane TF, Sage EH, Werb Z (1993) SPARC, a secreted protein associated with morphogenesis and tissue remodelling, induces expression of metalloproteinases in fibroblasts through a novel extracellular matrix-dependent pathway. J Cell Biol 121: 1433-1444

\section{Major fetal complications in optimised pregestational diabetes mellitus}

\section{Dear Sir,}

In a recently published article, L. Suhonen, V. Hiilesmaa and $\mathrm{K}$. Teramo assessed the relation between glycaemic control in early pregnancy and the risk of congenital malformations in a sample of 709 offspring of 488 women with Type I (insulindependent) diabetes mellitus compared with unselected nondiabetic women [1]. They observed that the frequency of major fetal malformations was higher in Type I diabetic women and even a slightly raised $\mathrm{HbA}_{1 \mathrm{c}}$ carried an increased risk for fetal malformations. Results for fetal mortality were not given. The authors concluded that normoglycaemia should be strived for during early pregnancy. These results contrast with previous suggestions according to which there is a broad range of glycaemic control within which the risk of malformations is not substantially increased [2], but they are in agreement with the more recent American Diabetes Association's recommendations [3].

We have analysed a sample of consecutive and evolutive (more than 14 weeks of gestation) 2929 pregnancies, 2385 from non-diabetic women, 481 with gestational diabetes and 63 with pregestational diabetes (55 with Type I diabetes).

Corresponding author: Dr. W. Ricart, Unitat d'Endocrinologia, Diabetes i Nutricio, Hospital Universitari de Girona, Ctra. Franca s/n, 17007 Girona, Spain, e-mail: endocrino@htrueta. scs.es, Fax: + 34972212754
Women with gestational diabetes were excluded from this study. Of the diabetic women $94 \%$ and of the control subjects $91 \%$ were Caucasians. The patients were registered at the hospital as soon as the pregnancy was diagnosed. We considered $\mathrm{HbA}_{1 \mathrm{c}}$ values of less than $5.4 \%$ ( +2 standard deviation) to be normal. Compared with the control subjects, the women with diabetes had a shorter gestation $(36 \pm 3$ vs $39 \pm 1.9$ weeks, $p<0.001)$, but non significant differences were observed in maternal age $(29.2 \pm 4.8$ vs $29.6 \pm 4.9)$, body mass index $(24.2 \pm 4.9$ vs $23.6 \pm 4.1)$ or arterial hypertension (1.6 vs $0.2 \%)$. The mean $( \pm \mathrm{SD}) \mathrm{HbA}_{1 \mathrm{c}}$ was $4.2 \pm 0.4 \%$ in the control group (414 non-selected women) and $6.6 \pm 1.6 \%$ in the diabetic group $(p<0.001)$. Of the women with diabetes, $21(34 \%)$ were included in the pre-pregnancy metabolic optimisation programme. Their $\mathrm{HbA}_{1 \mathrm{c}}$ around the time of conception was $5.5 \pm 0.5 \%$ in contrast with $7.3 \pm 1.6 \%$ in the pre-pregnancy, non-optimised diabetic women $(p<0.001)$. The frequency of fetuses with malformations was $6.3 \%$ in diabetic patients and $1.9 \%$ in the control women $(p=0.03$; relative risk $(\mathrm{RR})=1.04, \mathrm{CI}=0.98-1.12$ vs $\mathrm{RR}=0.29, \mathrm{CI}=0.11-0.80)$, $1 / 21(4.8 \%)$ in pre-pregnancy optimised diabetic women and $3 / 42(7.1 \%)$ in non-optimised women $(p=0.5)$. The fetal and neonatal mortality was $17.7 \%$ in diabetic women and $0.6 \%$ in control women $(p<0.0001, \quad \mathrm{RR}=20.8 \mathrm{CI}=12.4-35.1$ vs $\mathrm{RR}=0.57 \mathrm{CI}=0.4-0.8), 0 / 21(0 \%)$ in pre-pregnancy optimised diabetic women and $12 / 43(28 \%)$ in non-optimised women $(p=0.005)$. Major fetal complication, defined as the presence of fetal malformation or fetal/neonatal mortality, was more frequent in diabetic women $(22.6 \%$ vs $2.2 \%, p=0.00001$; $\mathrm{RR}=10.3 \mathrm{CI}=6.0-17.8$ vs $\mathrm{RR}=0.81 \mathrm{CI}=0.71-0.91$ ). In a logistic regression with occurrence of a major fetal complication, only $\mathrm{HbA}_{1 \mathrm{c}}$ with a $p$ value of 0.00001 was associated with a 